\title{
The Choice of Polar Stationary Phases for Gas-Liquid Chromatography by Statistical Analysis of Retention Data
}

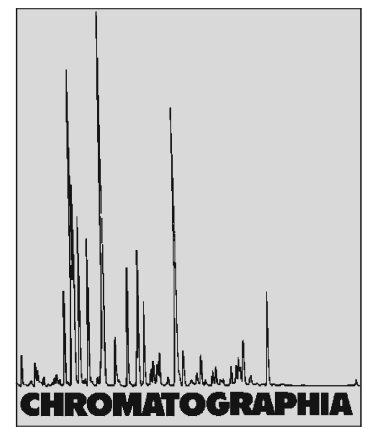

2009, 70, 831-837

\author{
Ervin sz. Kováts, Stephan Morgenthaler ${ }^{\boxplus}$ \\ École Polytechnique Fédérale de Lausanne, FSB-ISIC, Station 6, 1015 Lausanne, Switzerland; E-Mail: stephan.morgenthaler@epfl.ch
}

Received: 13 February 2009 / Revised: 13 May 2009 / Accepted: 5 June 2009

Online publication: 6 August 2009

\begin{abstract}
We have studied the retention indices of 127 volatile substances on a $C_{78}$-paraffin and on its seven nearly isochor and isomorphous polar derivatives over a temperature range of 90-210 ${ }^{\circ} \mathrm{C}$. The retention index of a substance on the $C_{78}$ paraffin has been considered as the standard. The additional retention on the polar derivative was given by the difference of its retention index on the polar solvent and on the $\mathrm{C}_{78}$-paraffin. Statistical analyses of the additional retention have shown that with respect to retention, the seven polar solvents can be classified into three groups: Type I: TTF (tetrakistrifluoromethyl), MTF (monotrifluoromethyl), Type II: PCN (primary cyano), PSH (primary thiol) and Type III: TMO (tetramethoxy), SOH (secondary alcohol) and $\mathrm{POH}$ (primary alcohol). It is shown that these three types are best represented by the solvents TTF, PCN and TMO. PSH (primary thiol) is aligned with PCN at temperatures up to about $150^{\circ} \mathrm{C}$, but is similar to $\mathrm{TMO}$ at $210^{\circ} \mathrm{C}$.
\end{abstract}

\section{Keywords}

Gas chromatography

Retention indices on polar stationary phases

\section{Introduction}

Gas/liquid retention data have been determined on the family of nearly isochor and isomorphous liquid stationary phases shown in Table 1 [1-4]. Corrected retention indices and standard chemical potential differences related to molal Henry coefficients (Standard chemical POTential difference $\equiv$ SPOT) of 127 solutes have been determined on all stationary phases. The data refer to the branched hydrocarbon stationary phase of carbon number 78, called "alkane $\mathrm{C}_{78}$ ", with a melting point of about $80^{\circ} \mathrm{C}$ and on seven thermally stable polar derivatives of this branched paraffin (see Table 1 and [5]). Because of a lack of thermal stability, a bromo derivative was left out of the analysis reported in this paper. Data in the polar solvents are given relative to those measured in the $\mathrm{C}_{78}$. hydrocarbon with no polar interacting group. As originally published, the determined indices contained small errors, especially at higher temperatures. The data have been corrected and are published in [5]. They can be downloaded from [doi:10.1016/ j.chroma.2006.01.123].

The retention index of the $j$ th substance, $I_{j}$, is calculated by interpolation of the logarithm of its net retention time, $\lg \left(t_{N, j}\right)$, between those of the neighboring $n$-alkanes measured under identical experimental conditions. It is easy to show that in the case of ideal gas-liquid chromatography (no adsorption) this is equivalent to the interpolation of the corresponding SPOT of a solute, $\Delta \mu_{j}$, between the SPOT-s of the two neighboring $n$-alkanes, $\Delta \mu_{z}$ and $\Delta \mu_{z+1}$, of carbon number, $z$ and $z+1$ :

$$
\begin{aligned}
I_{j} & =100\left[\frac{\lg \left(t_{N, j}\right)-\lg \left(t_{N, z}\right)}{\lg \left(t_{N, z+1}\right)-\lg \left(t_{N, z}\right)}\right]+100 z \\
& =100\left[\frac{\Delta \mu_{j}-\Delta \mu_{z}}{\Delta \mu_{z+1}-\Delta \mu_{z}}\right]+100 z
\end{aligned}
$$

where the retention times $t_{N, j}, t_{N, z}$ and $t_{N, z+1}$ are at the same temperature, $T$. At a given temperature the retention index of a solute defines on a logarithmic scale the place where a hypothetical $n$-alkane with the carbon number $I_{j} / 100$ would appear. The retention index of a normal 
Table 1. Structure of the paraffin hydrocarbon $\mathrm{C}_{78}$ and its seven polar derivatives

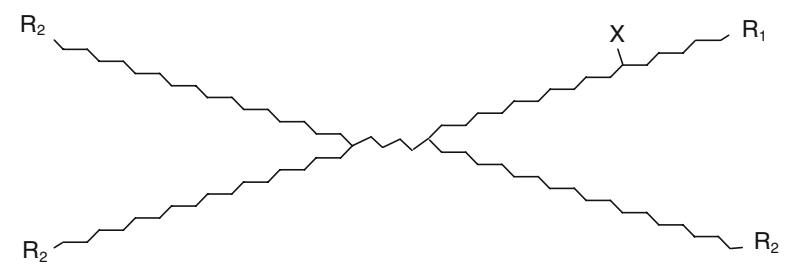

\begin{tabular}{|lllllll|}
\hline $\mathrm{P}$ & Polar interacting group(s) & $\mathrm{R}_{1}$ & $\mathrm{R}_{2}$ & $\mathrm{X}$ & $\mathrm{Ref}$. & $\begin{array}{l}\text { Corrected } \\
\text { indices }\end{array}$ \\
\hline $\mathrm{C}_{78}$ & - & & & & & \\
TTF & Tetrakistrifluoromethyl & $\mathrm{CH}_{2} \mathrm{CH}_{3}$ & $\mathrm{CH}_{2} \mathrm{CH}_{3}$ & $\mathrm{H}$ & {$[1]$} & {$[5]$} \\
MTF & Monotrifluoromethyl & $\mathrm{CH}_{2} \mathrm{CF}_{3}$ & $\mathrm{CH}_{2} \mathrm{CF}_{3}$ & $\mathrm{H}$ & {$[2]$} & {$[5]$} \\
PCN & Primary cyano & $\mathrm{CH}_{2} \mathrm{CH}_{3}$ & $\mathrm{H}$ & {$[2]$} & {$[5]$} \\
PSH & Primary thiol & $\mathrm{CH}_{2} \mathrm{SH}$ & $\mathrm{CH}_{2} \mathrm{CH}_{3}$ & $\mathrm{H}$ & {$[3]$} & {$[5]$} \\
TMO & Tetramethoxy & $\mathrm{CH}_{2} \mathrm{CH}_{3}$ & $\mathrm{H}$ & {$[3]$} & {$[5]$} \\
SOH & Secondary alcohol & $\mathrm{OCH}_{3}$ & $\mathrm{OCH}_{3}$ & $\mathrm{H}$ & {$[3]$} & {$[5]$} \\
POH & Primary alcohol & $\mathrm{CH}_{3}$ & $\mathrm{CH}_{2} \mathrm{CH}_{3}$ & $\mathrm{OH}$ & {$[4]$} & {$[5]$} \\
& & $\mathrm{CH}_{2} \mathrm{OH}$ & $\mathrm{CH}_{2} \mathrm{CH}_{3}$ & $\mathrm{H}$ & {$[1]$} & {$[5]$} \\
\hline
\end{tabular}

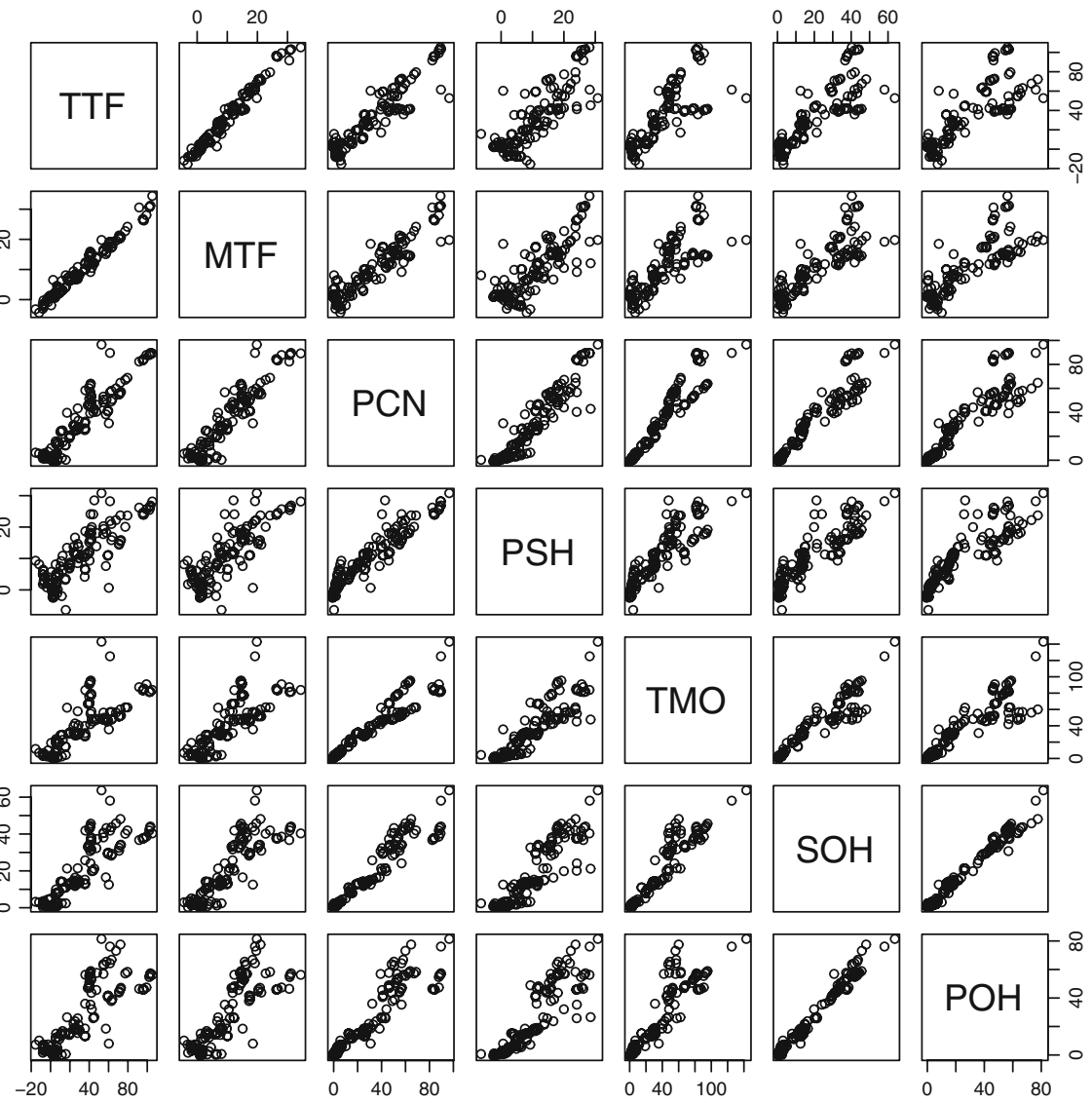

Fig. 1. The matrix of scatter plots of the additional retention of all pairs of stationary phases. In general, any pair of solvents produces additional retention index values that are tightly clustered around a straight line, which implies that any two solvents have positively correlated $\Delta I_{j}^{P}$ values. The stationary phases are grouped by type I: TTF, MTF, type II: PCN, PSH and type III: TMO, $\mathrm{SOH}, \mathrm{POH}$ alkane of carbon number, $z$, is defined at all temperatures as $I_{z}=100 z$.

The temperature dependence of the retention index on a stationary phase $P$ is given by the quadratic equation

$I_{j}^{P}(T)=I_{j}^{P}\left(T^{\dagger}\right)+A_{T, j}^{P} \Delta T+A_{T T, j}^{P} \Delta T^{2}$

where the temperature $T^{\dagger}=150^{\circ} \mathrm{C}$ is chosen in the middle of the temperature range of the determination of the experimental data and $\Delta T=T-T^{\dagger}$. The temperature dependence of the index is in general small and nearly linear. In our analysis, the indices determined on the polar derivative, are for each stationary phase $P$ given as differences

$\Delta I_{j}^{P}\left(T^{\dagger}\right)=I_{j}^{P}\left(T^{\dagger}\right)-I_{j}^{C 78}\left(T^{\dagger}\right)$

where the symbol, $\Delta$, designates a difference with reference of the $\mathrm{C}_{78}$ standard paraffin hydrocarbon.

A statistical analysis of the original data published in [6] had the aim to predict the boiling point and certain distribution coefficients of the solutes. The corrections of the retention data at high temperatures are of an order that they do not invalidate the conclusions of [6]. The aim of this paper is to choose those polar phases that are different and represent all polar phase information.

\section{Retention on the Polar Stationary Phases}

\section{Scatter Plots of the Additional Retention}

We put now forward the question if all polar stationary phases assure a different characterization of a mixture. Indeed, the $\Delta I$-values are different on all phases, but they can be correlated. A good correlation can be obtained between data on the two trifluoro substituted phases. Figure 2 shows that the additional retention on the tetrakistrifluoromethyl phase (TTF) is systematically about 3.3 times higher than those on the monotrifluoromethyl derivative (MTF). This means, that the chromatogram on the MTF phase can be reproduced by a 
chromatogram of a TTF-phase diluted by the $\mathrm{C}_{78}$-hydrocarbon.

The individual panels in Fig. 1 show scatter plots of the additional retention in one polar phase as a function of the additional retention in a second polar phase. Since we have seven polar phases, constructing all these scatter plots gives a 7 by 7 matrix of panels. The first row of Fig. 2 shows the additional retention on TTF as a function of the additional retention in the other six stationary phases. The second row does the same for MTF, and so on. The slope for predicting TTF with the help of MTF is 3.45. Inversely, when explaining MTF with the help of TTF, or the ratio MTF/ TTF, the slope is $1 / 3.45=0.29$. The other slopes are as follows: $\mathrm{TTF} /$ $\mathrm{PCN}=1.14, \quad \mathrm{TTF} / \mathrm{PSH}=4.16, \quad \mathrm{TTF} /$ $\mathrm{TMO}=0.99, \mathrm{TTF} / \mathrm{SOH}=2.06, \mathrm{TTF} /$ $\mathrm{POH}=1.41, \mathrm{MTF} / \mathrm{PCN}=0.31, \mathrm{MTF} /$ $\mathrm{PSH}=1.04, \mathrm{MTF} / \mathrm{TMO}=0.25, \mathrm{MTF} /$ $\mathrm{SOH}=0.51, \mathrm{MTF} / \mathrm{POH}=0.34, \mathrm{PCN} /$ $\mathrm{PSH}=3.28, \mathrm{PCN} / \mathrm{TMO}=0.87, \mathrm{PCN} /$ $\mathrm{SOH}=1.7, \quad \mathrm{PCN} / \mathrm{POH}=1.19, \quad \mathrm{PSH} /$ $\mathrm{TMO}=0.25, \quad \mathrm{PSH} / \mathrm{SOH}=0.5, \quad \mathrm{PSH} /$ $\mathrm{POH}=0.34, \mathrm{TMO} / \mathrm{SOH}=1.95, \mathrm{TMO} /$ $\mathrm{POH}=1.38, \mathrm{SOH} / \mathrm{POH}=0.71$.

\section{Box Plots of the Additional Retention}

Figure 2 shows a summary of the 127 retention index differences, $\Delta I_{j}^{P}$, in the form of box plots for each of the seven polar solvents (see [7, 8] for more details on box plots). With very few exceptions, the values of $\Delta I_{j}^{P}$ are positive, that is, the retention index in a polar solvent is higher than that on $\mathrm{C}_{78}$. This reflects the lack of interactive groups in the $\mathrm{C}_{78}$. Solvents with large $\Delta I_{j}^{P}$ values are TTF, TMO and PCN. MTF and PSH have the smallest $\Delta I_{j}^{P}$-values.

The box plots show the distribution of the variable $\Delta I_{j}^{P}$ for each solvent separately, but they cannot show, how $\Delta I_{j}^{P}$ behaves for pairs of solvents. This joint distribution of the additional retention index is exhibited in Fig. 2.

\section{Principal Components}

The analysis by principal components is a statistical procedure, which can be

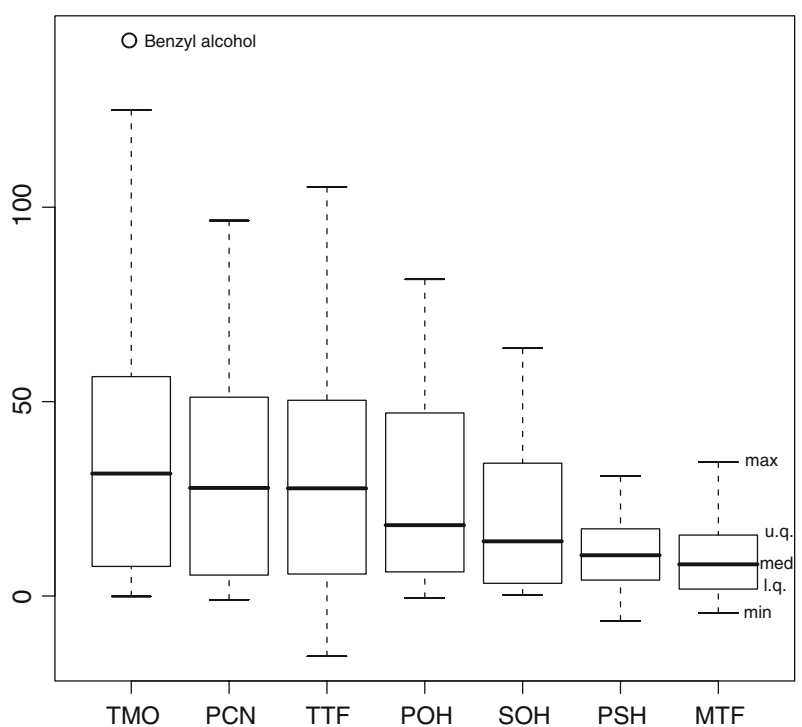

Fig. 2. Box plots of the variable $\Delta I_{j}^{P}$ (additional retention) for the seven polar solvents, where the additional retention is the difference of the retention index between the stationary phase $j$ and the standard $\mathrm{C}_{78}$. Each box corresponds to one stationary phase and shows the distribution of the corresponding $127 \Delta I_{j}^{P}$ values. The box extends from the lower quartile (l.q.) to the higher quartile (h.q.), with the median value (med) indicated by a horizontal separator. The box thus shows the middle half of the additional retentions. The whiskers attached to the box extend to the largest $(\max )$ and smallest $(\min )$ values. Below the box and above the box are one quarter of the additional retentions. The scale on the left-hand side applies to all seven box plots. The lower whiskers only rarely extend to negative values, which shows that a large majority of the additional retentions are positive. The seven stationary phases are ordered by the median line. The median is largest for TMO and smallest for MTF

Table 2. The loadings of the first and second principal components

\begin{tabular}{|lllllrrr|}
\hline & $v_{k}^{\mathrm{TTF}}$ & $v_{k}^{\mathrm{MTF}}$ & $v_{k}^{\mathrm{PCN}}$ & $v_{k}^{\mathrm{PSH}}$ & \multicolumn{1}{c}{$v_{k}^{\mathrm{SOH}}$} & $v_{k}^{\mathrm{POH}}$ & \multicolumn{1}{c|}{$v_{k}^{\mathrm{TMO}}$} \\
\hline First PC $(k=1)$ & 0.47 & 0.14 & 0.47 & 0.15 & 0.28 & 0.39 & 0.47 \\
Second PC $(k=2)$ & 0.78 & 0.19 & 0.04 & -0.04 & -0.16 & -0.25 & -0.51 \\
\hline
\end{tabular}

applied to data consisting of several variables measured on the same substances. If variables are intercorrelated, it is sometimes possible to reduce their number without much loss of information. As seen in Fig. 1 our seven extra retentions on different polar stationary phases are highly correlated and are such inter-related variables. How many of the seven are redundant and how many are really needed? We denoted the extra retentions by $\Delta I_{j}^{P}$, where the stationary phase $P$ is either TTF, MTF, PCN, PSH, $\mathrm{TMO}, \mathrm{SOH}$, or $\mathrm{POH}$. There are seven variables and also seven principal components. The $k$ th principal component is a linear combination of the variables, that is, of the form

$$
\begin{aligned}
C_{k, j}= & v_{k}^{\mathrm{TTF}} \Delta I_{j}^{\mathrm{TTF}}+v_{k}^{\mathrm{MTF}} \Delta I_{j}^{\mathrm{MTF}} \\
& +v_{k}^{\mathrm{PCN}} \Delta I_{j}^{\mathrm{PCN}}+v_{k}^{\mathrm{PSH}} \Delta I_{j}^{\mathrm{PSH}} \\
& +v_{k}^{\mathrm{TMO}} \Delta I_{j}^{\mathrm{TMO}}+v_{k}^{\mathrm{SOH}} \Delta I_{j}^{\mathrm{SOH}} \\
& +v_{k}^{\mathrm{POH}} \Delta I_{j}^{\mathrm{POH}}
\end{aligned}
$$

The weights or loadings, $v_{k}^{P}$, are chosen in such a way that the first principal component maximizes the variance, the second principal component is uncorrelated with the first and under this condition maximizes the variance, the third is uncorrelated with the other two and maximizes the variance, and so on. Of course, the constraints imposed on successive principal components become more and more limiting and the maximal 

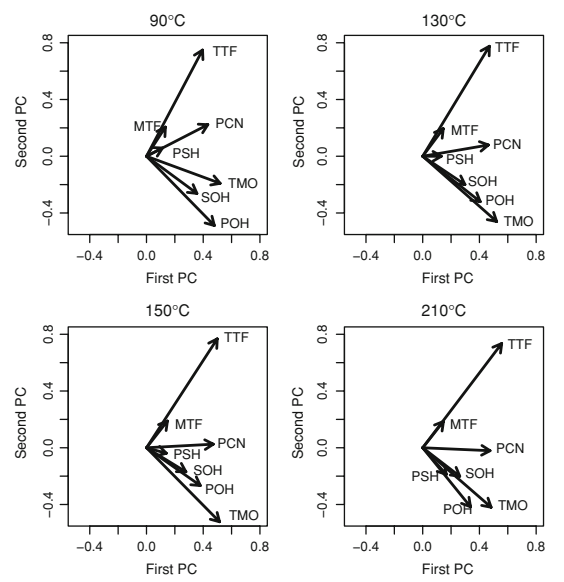

Fig. 3. Plot of the loadings for the two-first principal components for different temperatures in ${ }^{\circ} \mathrm{C}$. The grouping of the loading vectors changes across the temperature range. One attribute that remains constant is the separation between TTF and TMO as well as the fact that PCN remains in between these two. Of the other stationary phases, MTF stays with TTF, while PSH, SOH and $\mathrm{POH}$ change their behavior across the temperature range. At low temperatures, PSH is similar to PCN, at high temperatures it is similar to TMO. $\mathrm{SOH}$ and $\mathrm{POH}$ are close to each other and fluctuate around TMO. It is of interest to note that the fraction of the total variation explained by the first two principal components increases with temperature
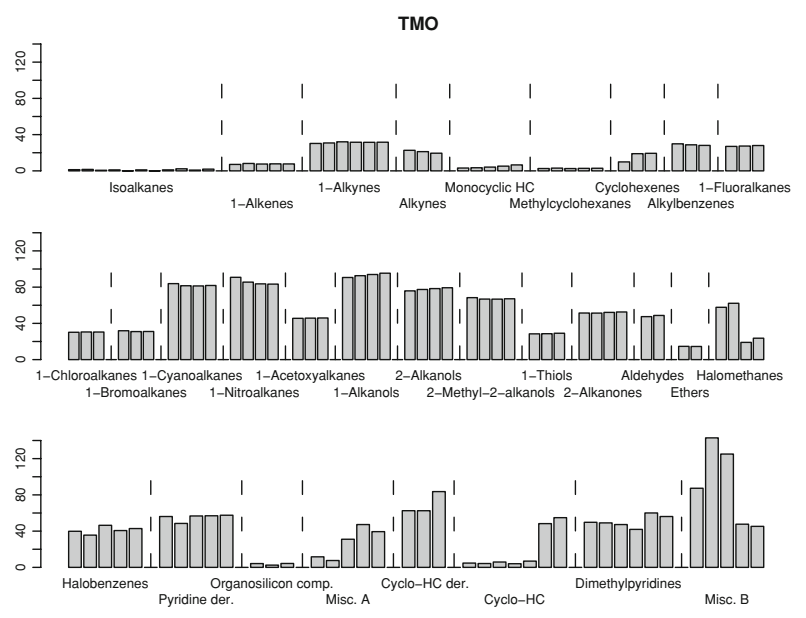

Fig. 5. Values of $\Delta I_{j}^{\mathrm{PCN}}$ at $150^{\circ} \mathrm{C}$ as a function of the substances on the stationary phase $\mathrm{PCN}$
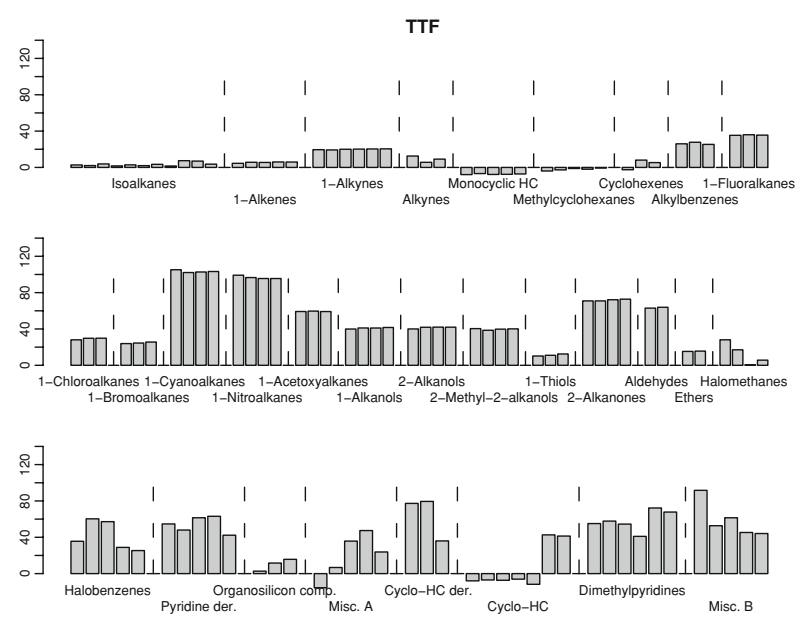

Fig. 4. Values of $\Delta I_{j}^{\mathrm{TTF}}$ at $150^{\circ} \mathrm{C}$ as a function of the substances on the stationary phase TTF
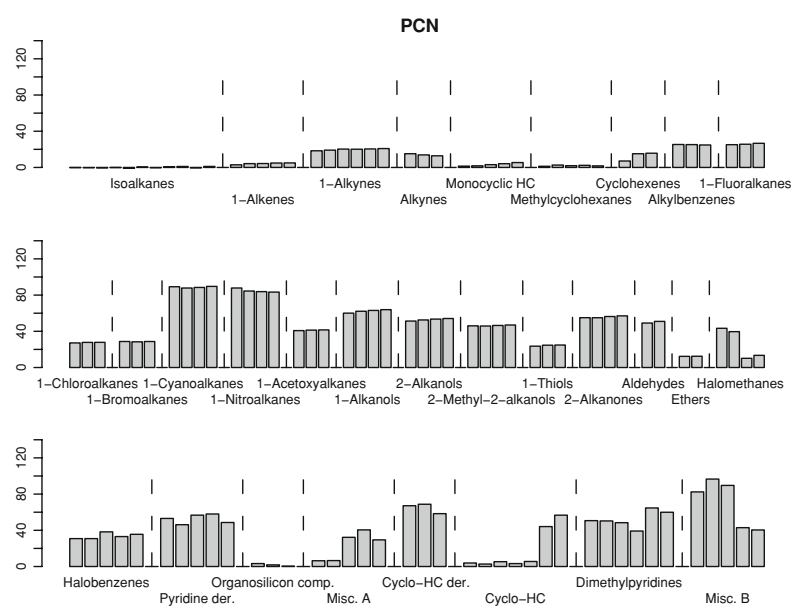

Fig. 6. Values of $\Delta I_{j}^{\mathrm{TMO}}$ at $150^{\circ} \mathrm{C}$ as a function of the substances on the stationary phase TMO variance achievable under the constraint becomes smaller and smaller. In this way, principal component analysis (PCA) can replace many variables by one or two principal components, which contain most of the total variance. The relative importance of each component is determined by the fraction of the total variance it explains. All seven components together explain $100 \%$ of the variation in the original data, the first six a little less than $100 \%$, and so on. A basic text on this statistical procedure, written for chemists, is found in [9].

In the data we analyze in this paper, the PCA is revealing. The first and most important components explains 96.2\% of the total variation in the variables $\Delta I_{j}^{P}$. This reflects the fact that the extra retentions on the seven polar phases are so strongly correlated that they can be successfully explained by an average extra retention. The first and the second components together increase this 
Table 3. The groups of substances shown in Figs. 4, 5, 6, 7, 8 and 9

\begin{tabular}{|c|c|c|c|c|}
\hline Isoalkanes & 1-Alkenes & 1-Alkynes & Alkynes & $\begin{array}{l}\text { Monocyclic } \\
\text { hydrocarbons (HC) }\end{array}$ \\
\hline $\begin{array}{l}\text { 2,2-Dimethylbutane } \\
\text { 2,3-Dimethylbutane } \\
\text { 2,2-Dimethylpentane } \\
\text { 2,3-Dimethylpentane } \\
\text { 2,4-Dimethylpentane } \\
\text { 2,3-Dimethylhexane } \\
\text { 2,4-Dimethylhexane } \\
\text { 3,4-Dimethylhexane } \\
\text { 2,2,3-Trimethylbutane } \\
\text { 2,2,4-Trimethylpentane } \\
\text { 2,3,4-Trimethylpentane }\end{array}$ & $\begin{array}{l}\text { 1-Hexene } \\
\text { 1-Heptene } \\
\text { 1-Octene } \\
\text { 1-Nonene } \\
\text { 1-Decene }\end{array}$ & $\begin{array}{l}\text { 1-Pentyne } \\
\text { 1-Hexyne } \\
\text { 1-Heptyne } \\
\text { 1-Octyne } \\
\text { 1-Nonyne } \\
\text { 1-Decyne }\end{array}$ & $\begin{array}{l}\text { 2-Hexyne } \\
\text { 3-Hexyne } \\
\text { 4-Octyne }\end{array}$ & $\begin{array}{l}\text { Cyclopentane } \\
\text { Cyclohexane } \\
\text { Cycloheptane } \\
\text { Cyclooctane } \\
\text { Cyclodecane }\end{array}$ \\
\hline Methylcyclohexanes & Cyclohexenes & Alkylbenzenes & 1-Fluoroalkanes & 1-Chloroalkanes \\
\hline $\begin{array}{l}\text { Methylcyclohexane } \\
\text { cis-1,2-Dimethylcyclohexane } \\
\text { trans-1,2-Dimethylcyclohexane } \\
\text { cis-1,4-Dimethylcyclohexane } \\
\text { trans-1,4-Dimethylcyclohexane }\end{array}$ & $\begin{array}{l}\text { Cyclohexene } \\
\text { 1,3-Cyclohexadiene } \\
\text { 1,4-Cyclohexadiene }\end{array}$ & $\begin{array}{l}\text { Benzene } \\
\text { Toluene } \\
\text { Ethylbenzene }\end{array}$ & $\begin{array}{l}\text { 1-Fluoropentane } \\
\text { 1-Fluorohexane } \\
\text { 1-Fluorooctane }\end{array}$ & $\begin{array}{l}\text { 1-Chlorobutane } \\
\text { 1-Chloropentane } \\
\text { 1-Chlorohexane }\end{array}$ \\
\hline 1-Bromoalkanes & 1-Cyanoalkanes & 1-Nitroalkanes & 1-Acetoxyalkanes & 1-Alkanols \\
\hline $\begin{array}{l}\text { 1-Bromopropane } \\
\text { 1-Bromobutane } \\
\text { 1-Bromopentane }\end{array}$ & $\begin{array}{l}\text { Cyanoethane } \\
\text { 1-Cyanopropane } \\
\text { 1-Cyanobutane } \\
\text { 1-Cyanopentane }\end{array}$ & $\begin{array}{l}\text { Nitroethane } \\
\text { 1-Nitropropane } \\
\text { 1-Nitrobutane } \\
\text { 1-Nitropentane }\end{array}$ & $\begin{array}{l}\text { 1-Acetoxypropane } \\
\text { 1-Acetoxybutane } \\
\text { 1-Acetoxypentane }\end{array}$ & $\begin{array}{l}\text { 1-Butanol } \\
\text { 1-Pentanol } \\
\text { 1-Hexanol } \\
\text { 1-Heptanol }\end{array}$ \\
\hline 2-Alkanols & 2-Methyl-2-alkanols & 1-Alkanethiols & 2-Alkanons & Aldehydes \\
\hline $\begin{array}{l}\text { 2-Butanol } \\
\text { 2-Pentanol } \\
\text { 2-Hexanol } \\
\text { 2-Heptanol }\end{array}$ & $\begin{array}{l}\text { 2-Methyl-2-propanol } \\
\text { 2-Methyl-2-butanol } \\
\text { 2-Methyl-2-pentanol } \\
\text { 2-Methyl-2-hexanol }\end{array}$ & $\begin{array}{l}\text { 1-Butanthiol } \\
\text { 1-Pentanthiol } \\
\text { 1-Hexanthiol }\end{array}$ & $\begin{array}{l}\text { 2-Butanone } \\
\text { 2-Pentanone } \\
\text { 2-Hexanone } \\
\text { 2-Heptanone }\end{array}$ & $\begin{array}{l}\text { Pentanal } \\
\text { Hexanal }\end{array}$ \\
\hline Ethers & Halomethanes & Halobenzenes & Pyridine derivatives & $\begin{array}{r}\text { Organosilicon } \\
\text { compounds } \\
\end{array}$ \\
\hline $\begin{array}{l}\text { Dipropyl-ether } \\
\text { Dibuthyl-ether }\end{array}$ & $\begin{array}{l}\text { Dichloromethane } \\
\text { Trichloromethane } \\
\text { Tetrachloromethane } \\
\mathrm{CF}_{2} \mathrm{Br}_{2}\end{array}$ & $\begin{array}{l}\text { Fluorobenzene } \\
\text { Hexafluorobenzene } \\
\text { Trifluoromethylbenzene } \\
\text { Chlorobenzene } \\
\text { Bromobenzene }\end{array}$ & $\begin{array}{l}\text { Pyridine } \\
\text { 2-Methylpyridine } \\
\text { 3-Methylpyridine } \\
\text { 4-Methylpyridine } \\
\text { 3-Chloropyridine }\end{array}$ & $\begin{array}{l}\text { Tetramethylsilane } \\
\text { Hexamethyldisilane } \\
\text { Hexamethyldisiloxane }\end{array}$ \\
\hline Miscellaneous A & Cyclohydrocarbon derivatives & Cyclohydrocarbons & Dimethylpyridines & Miscellaneous B \\
\hline $\begin{array}{l}\text { Carbondisulfide } \\
\text { Tetramethyltin } \\
\text { Tetrahydrofurane } \\
\text { 1,4-Dioxane } \\
\text { Thiophene }\end{array}$ & $\begin{array}{l}\text { Cyclopentanon } \\
\text { Cyclohexanon } \\
\text { Cyclohexanol }\end{array}$ & $\begin{array}{l}\text { cis-Hydrindane } \\
\text { trans-Hydrindane } \\
\text { cis-Decaline } \\
\text { trans-Decaline } \\
\text { Adamantane } \\
\text { Naphthalene } \\
\text { Azulene }\end{array}$ & $\begin{array}{l}\text { 2,3-Dimethylpyridine } \\
\text { 2,4-Dimethylpyridine } \\
\text { 2,5-Dimethylpyridine } \\
\text { 2,6-Dimethylpyridine } \\
\text { 3,4-Dimethylpyridine } \\
\text { 3,5-Dimethylpyridine }\end{array}$ & $\begin{array}{l}\text { Nitrobenzene } \\
\text { Benzyl alcohol } \\
\text { 2-Phenylethanol } \\
\text { Anisol } \\
\text { Ethoxybenzene }\end{array}$ \\
\hline
\end{tabular}

percentage to $98.8 \%$. Hence, only $1.2 \%$ of the information is not captured by these two principal components (Table 2).

It is not difficult to interpret the loading of the first principal component. The most important loadings are given to TTF, PCN and TMO (value of 0.47 ). The smallest loadings are given to MTF and PSH (value of around 0.15). The weight 0.47 given to TTF is 3.3 times as large as the one given to MTF. Hence, these coefficients give large weight to the stationary phases with big extra retention (see Fig. 2) and the smallest weight to those with small additional retention and the relative importance reflects the slopes we observed in Fig. 1. The second principal component has positive and negative loadings and describes a contrast between the extra retention in the stationary phases TTF and TMO. All other phases have small loadings.

A visual analysis of the loadings is obtained by plotting the vectors $\left[v_{1}^{P}, v_{2}^{P}\right]$ for the seven polar stationary phases. Figure 3 shows the vectors of loadings at different temperatures. 

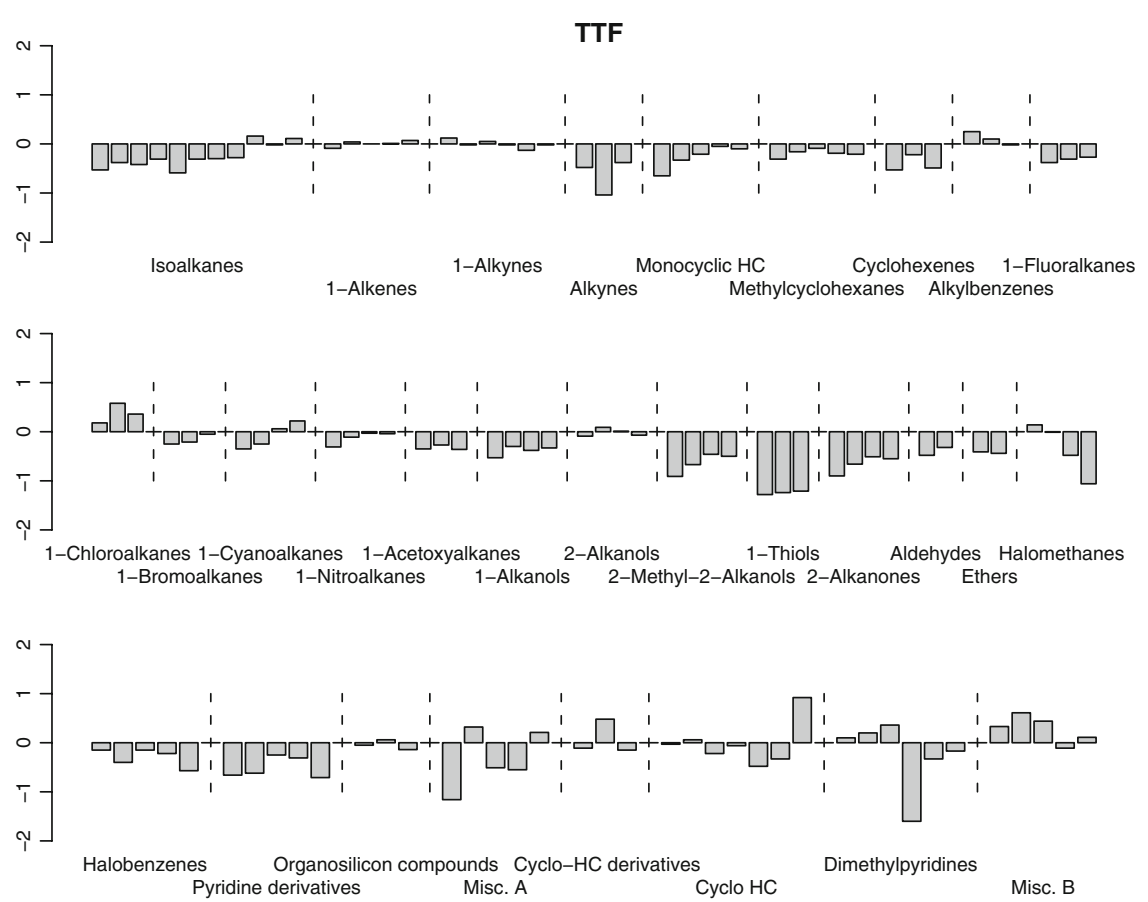

Fig. 7. Temperature dependence of the retention index per $10^{\circ} \mathrm{C}$ between 125 and $175^{\circ} \mathrm{C}$ on the stationary phase $\mathrm{TTF}$ : values of $\left(\Delta I_{j}^{\mathrm{TTF}}\left[175^{\circ} \mathrm{C}\right]-\Delta I_{j}^{\mathrm{TTF}}\left[125^{\circ} \mathrm{C}\right]\right) / 5$

TMO
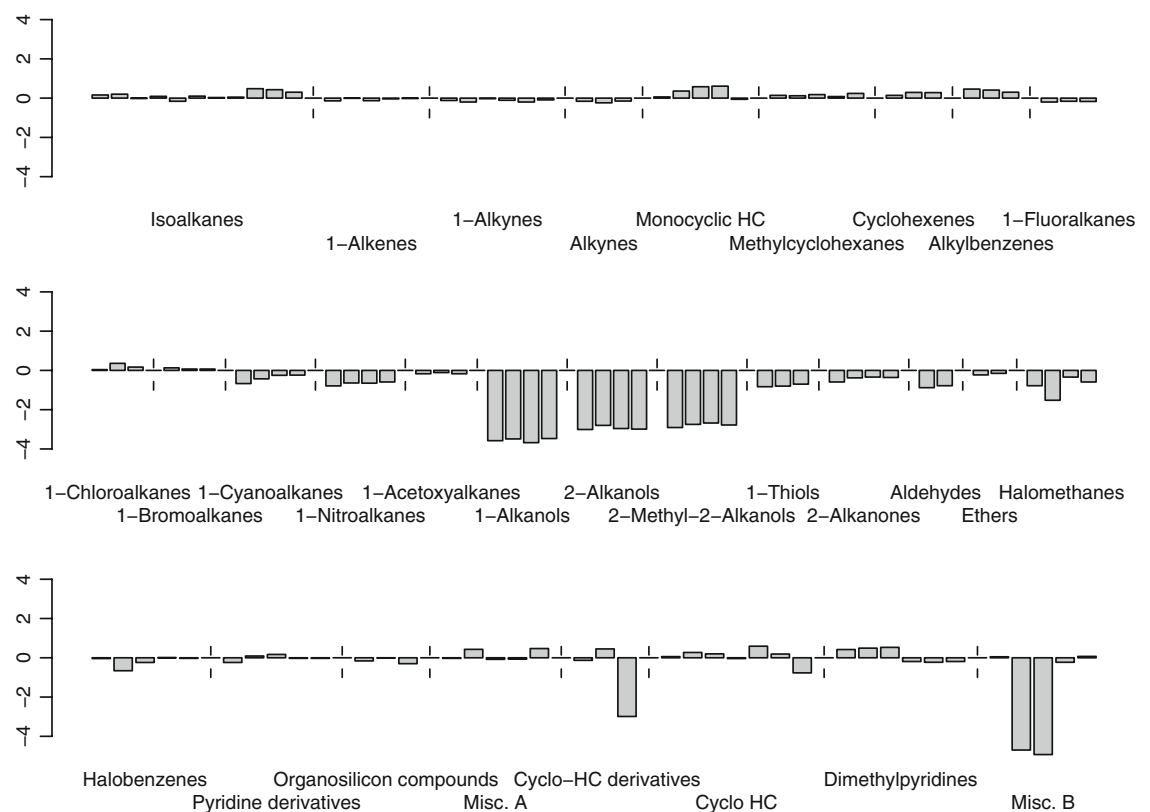

Fig. 8. Temperature dependence of the retention index per $10^{\circ} \mathrm{C}$ between 125 and $175^{\circ} \mathrm{C}$ on the stationary phase $\mathrm{PCN}$ : values of $\left(\Delta \mathrm{I}_{j}^{\mathrm{PCN}}\left[175^{\circ} \mathrm{C}\right]-\Delta \mathrm{I}_{j}^{\mathrm{PCN}}\left[125^{\circ} \mathrm{C}\right]\right) / 5$

\section{Conclusions}

This analysis shows that the seven polar stationary phases under consideration are well represented by TTF, PCN and TMO across a large temperature range. Figures 4, 5 and 6 show the extra retention of the 127 substances at these three selected stationary phases. Table 3 lists the substances. Of the remaining solvents, MTF is grouped with TTF and $\mathrm{POH}$ whereas $\mathrm{SOH}$ is grouped with TMO. PSH has a small polarity effect and behaves similarly to PCN at low temperatures and to TMO at higher temperatures. Because MTF and TTF are closely linked, one could also choose MTF as a representative. However, larger and more clearly visible effects are obtained with TTF.

The effect of the temperature on the $\Delta I_{j}^{P}$-value over a limited temperature range is well-described by a quadratic equation, which is closely approximated by a linear function. Figures 7,8 and 9 show $\left(\Delta I_{j}^{P}\left[175^{\circ} \mathrm{C}\right]-\Delta I_{j}^{P}\left[125^{\circ} \mathrm{C}\right]\right) / 5$, that is, the change of the $\Delta I_{j}^{P}$-value of a substance for $10^{\circ} \mathrm{C}$ around the median temperature of $150{ }^{\circ} \mathrm{C}$ for the three selected stationary phases.

\section{Acknowledgment}

We would like to thank the reviewer for the careful reading and the constructive remarks.

\section{References}

1. Reddy KS, Dutoit J-CL, sz. Kováts E (1992) J Chromatogr A 609:229-259. doi: 10.1016/0021-9673(92)80167-S

2. Reddy KS, Cloux R, sz. Kováts E (1994) J Chromatogr A 673:181-209. doi: 10.1016/0021-9673(94)85037-2

3. Reddy KS, Cloux R, sz. Kováts E (1995) J Chromatogr A 704:387-436. doi: 10.1016/0021-9673(95)93206-B

4. Dallos A, Sisak A, Kulcsár Z, sz. Kováts E (2000) J Chromatogr A 904:211-242. doi: 10.1016/S0021-9673(00)00908-0

5. E sz. Kováts, R Kresz (2006) J Chromatogr A 1113:206-219. doi:10.1016/j. chroma.2006.01.123 

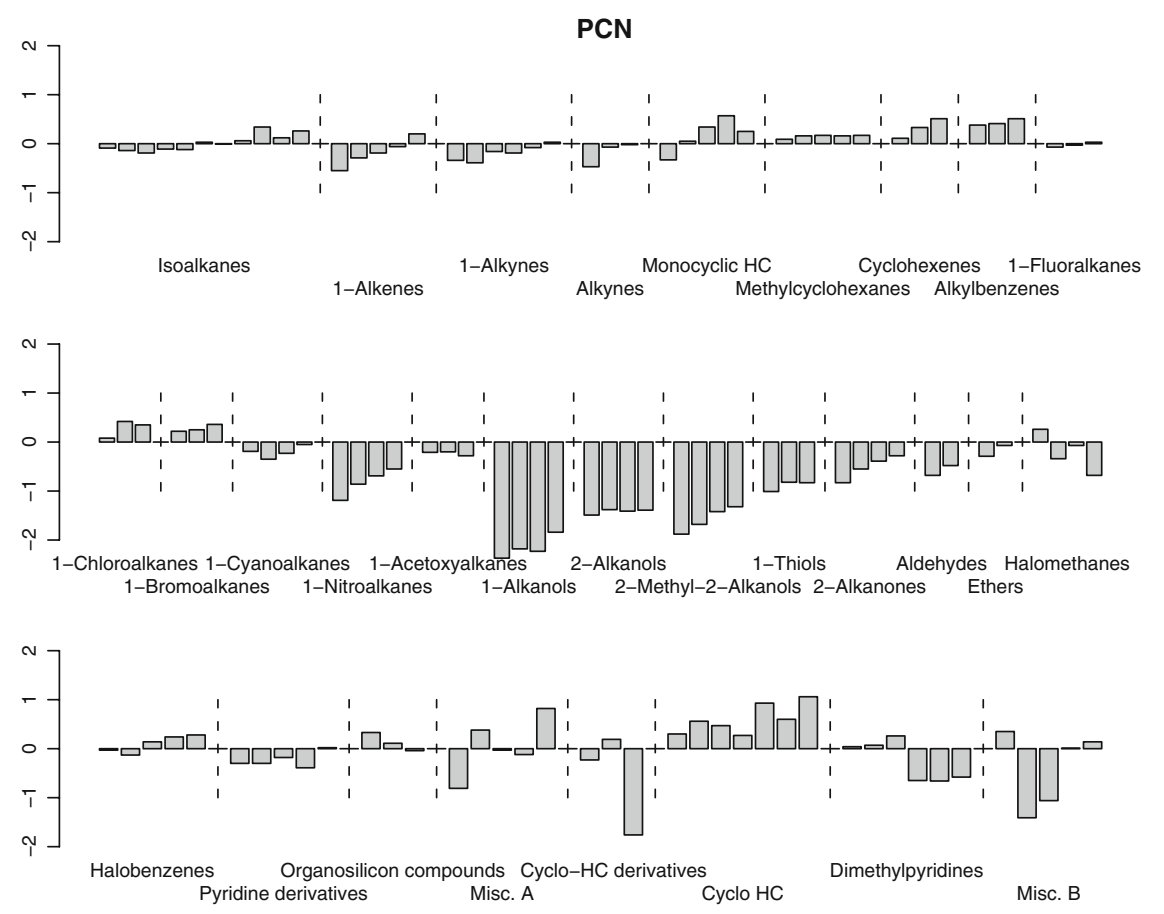

Fig. 9. Temperature dependence of the retention index per $10{ }^{\circ} \mathrm{C}$ between 125 and $175{ }^{\circ} \mathrm{C}$ on the stationary phase TMO: values of $\left(\Delta I_{j}^{\mathrm{TMO}}\left[175^{\circ} \mathrm{C}\right]-\Delta I_{j}^{\mathrm{TMO}}\left[125^{\circ} \mathrm{C}\right]\right) / 5$
6. Dallos A, Ngo HS, Kresz R, Héberger K (2008) J Chromatogr A 1177:175-182. doi: 10.1016/j.chroma.2007.11.034

7. Tukey JW (1977) Exploratory data analysis. Academic Press, USA

8. McGill R, Tukey JW, Larsen WA (1978) Am Stat 32:12-16

9. Malinowski ER (2002) Factor analysis in chemistry, 3rd edn. Wiley, New York 